\title{
Trade Unions and the Belo Horizonte Bank Workers Union Strike: Obstacles and Motivating Factors to the Movement for the Constitution of Class Consciousness
}

\author{
Sindicatos e a Greve Sindical dos Bancários de \\ Belo Horizonte: Obstáculos e Potencialidades ao \\ Movimento de Constituição da Consciência de \\ Classe
}

\author{
Henrique Leão Coelho* \\ Deise Luiza da Silva Ferraz **
}

\begin{abstract}
In this article, the necessary and contingent class consciousness and the union organization are discussed as an obstacle and potentiating practice of the concrete movement of the constitution of the consciousness of the historical task of the workers. A study was carried out with bank workers during the strikes of 2013 and 2014. Interviews, systematic observations and documental analysis provided an opportunity for the formation of the empirical corpus that supports the analytical generalizations made. The interviews were conducted with members of Banco do Brasil and Caixa Econômica Federal and were carried out up to the point of saturation. The conditions that hinder the movement of class consciousness of the working class when they carry in themselves the potentiality of criticism and denial of the way in which labor consents to capital can be described in five large sets to be exposed and debated in the text. These determinations include union structure, bureaucratization, people management techniques, the strike simulation and the unsatisfactory achievements made in the face of real class demands.
\end{abstract}

Keywords: Social Classes. Class Consciousness. Trade Union.

\footnotetext{
* Doutorando e mestre na linha de Estudos Organizacionais, Trabalho e Sociedade em Administração pela Faculdade de Ciências Econômicas (FACE) da Universidade Federal de Minas Gerais (UFMG). Bacharel e Licenciado em Ciências Sociais pela Faculdade de Filosofia e Ciências Humanas (FAFICH) da Universidade Federal de Minas Gerais (UFMG). rickcoelholda@ hotmail.com

${ }^{* *}$ Doutora, Mestra e Bacharela em Administração pela Universidade Federal do Rio Grande do Sul, com um período de estágio-doutoral no Centro de Investigação em Sociologia Econômica e das Organizações (SOCIUS) do Instituto Superior de Economia e Gestão da Universidade Técnica de Lisboa. Professora Adjunta no Departamento de Ciências Administrativas e Professora Permanente do Centro de Pós-Graduação e Pesquisa em Administração (Cepead) da Faculdade de Ciências Econômicas (FACE) da Universidade Federal de Minas Gerais (UFMG). deiseluiza@face.ufmg.br
} 
Resumo: Nesse artigo, são discutidas a consciência de classe necessária e contingente e a organização sindical enquanto uma prática obstaculizadora e potencializadora do movimento concreto da constituição da consciência da tarefa histórica dos trabalhadores. Foi realizado um estudo com trabalhadores bancários durante as greves de 2013 e 2014. Entrevistas, observações sistemáticas e análise documental oportunizaram a formação do corpus empírico que dá sustentação às generalizações analíticas efetuadas. As entrevistas, por sua vez, foram realizadas com membros do Banco do Brasil e da Caixa Econômica Federal, sendo efetivadas até o ponto de saturação. Os condicionantes que obstaculizam o movimento de consciência de classe da classe trabalhadora quanto carregam em si a potencialidade de crítica e negação da forma com que o trabalho consente ao capital podem ser descritos em cinco grandes conjuntos a serem expostos e debatidos no texto. Essas determinações passam pela estrutura sindical, burocratização, técnicas de gestão de pessoas, a simulação grevista e as insatisfatórias conquistas efetivadas frente as reais demandas da classe.

Palavras-chave: Classes sociais. Consciência de Classe. Organização Sindical

Recebido em 23/11/2018. Aceito em 03/08/2020

\section{Introduction}

The emancipation of the human kind is the work of the working class, Marx and Engels mentioned in the 19th Century. Marx also pointed out that the working class would understand how the trade union's struggle which aims at the contingent interests is only the means to the abolition of the wage labor system, with this being the necessary interest to the overcoming of labor's self- alienation. These considerations emphasize the themes that we will discuss in this text: necessary and contingent class consciousness (MÉSZAROS, 2008) and contemporary trade unionism as a both hindering and potentializing practice of the concrete movement of constitution of a conscience regarding the workers' historical task. Thus, the goal of this text is to analyze the determinant factors of the banking workers' conscience molding to the interests of the capital. The discussion was supported by a study made during the 2013 and 2014 banking workers' strikes. Interviews, systematic observations and document analysis allowed the formation of the empiric corpus that supports the analytical generalizations that were made. These generalizations are supported by the theoretical discussions on trade unionism, social classes and class consciousness that we present in the next item of this text. In the following item, we briefly present the method that supported the data collection and, on item 4, the analytic-descriptive discussions are presented in order to offer a basis for the general reflexions presented on the final considerations.

Moreover, the problem in question lacks greater exposure. The trade union organisations represent one of the potential collective spaces of the path developed by class consciousness and present themselves here as a favorable object for the study of the transformative process of consciousness 
The unions "were born out of the effort of the working class in its struggle against despotism and the domination of Capital. (ANTUNES, p.12, 1985, author translation). They are institutions created by workers as a form of defence against the exploitation inherent in work in capitalism. They have the role of providing the means for the organization of demands that aim to alter precarious working conditions, from excessive workloads, low wages and non-compliance with labour legislation, among other interests that arise from the demands of the category represented. As a product of the workers, the union manages to group them and prevents the employer from treating each "worker" separately, representing them. It is, or for this purpose is instituted, in favour of the historical labour struggle, the unrestricted preservation of the basic rights of the worker, that the union organisation takes charge of commanding, organising and potentiating the demanding weapons, seeking greater efficiency in the defence and the labour offensive.

According to Marx (1980, p. 9, author translation), "the workers unite to put themselves on an equal footing with the capitalist for the contract of sale of their work. This is the reason (logical basis) for the unions".

However, by combating and easing the immediate conditions of constituent exploitation of labour in capitalism, struggles can advance to the foundations of a broader conquest. In their manifest and representative condition of the working class, the unions are a space for the promotion of the historical-social struggle for the emancipation of the workers, because, according to Marxian reflections, the necessary interest of the working class is to overcome the concrete conditions of their exploitation. Thus, if the actions planned by the unions more explicitly summarize the contingent interests of the class, they include, at the same time, the possibility of the progressive movement to form the necessary class consciousness by the workers to break the shackles that bind them to an exploitative mode of production.

In this endeavour, we will be dealing with a decisive moment in trade union practice, that is to say, the moment in which the strike is consigned as a possibility of overcoming contingent interests to necessary interests. However, it will be highlighted that the union, an expression of the workers' organisation, cannot be analysed for what it should be, but for what it is being, since its need to come is circumscribed to the sphere of ethical desire, and is realised to the extent that its historical determinants are understood, questioned and the basis for new demanding praxis. Therefore, it is necessary to understand and reflect on the actions of the unions, not as conceptual elements, that is, as essences endowed with immutability. On the contrary, it is necessary to investigate and analyse in the field of praxis, the concrete action of these organisms and this social performance, unravelling their self-dynamics, their accessibility, their predispositions, their efficiency and, finally, the congruence with their proposition: the strict defence of the worker's causes before the force of Capital and his progressive liberation from wage labour. As Marx puts it (1980, p. 11, author translation), "liberation is a historical fact and not an intellectual fact".

\section{Social classes: consciensce and instruments of struggle}

To comprehend how the human kind constitutes social groups of belonging in spite of individual wills is an element of numberless controversies. Marx explains this phenomenon through the analysis of the organization of the (re)productive process of human life in its humanity, which is grounded on three elements: object of labor, means of labor, and labor (the symbiosis of the double moment of ideation-action, of subjectivation-objectivation). The social distribution of these elements in the historical process of human sociability constitutes sets of indetermination 
that mediate the other social arrangements, acting on some as a predominant moment, and on others subsumed to other several elements constituted in and by the social relations.

The subjectivation of the primary objectivity deals with a far more complex relation than the class's immediate comprehension of belonging. The determination of class belonging does not need, then, to manifest itself as an immediate identification of this belonging; on the contrary, in an antagonistic society, in which the owners of the means of material production are also the owners of the means of producing ideas (MARX; ENGELS, 2007), the determination is manifested as contradictions in the being of the working class, before it is manifested in the identification as a working class. To discuss class consciousness, therefore, is to consider the essence of the discussion of social stratification, beyond its immediate manifestation of culturalidentity belonging.

\section{Class Consciousness}

"Where, after all, lives conscience; in the individual's particularity or in the class's generality?" (IASI, 2006. p. 23, author translation). From the individual conscience to the advances of group conscience and class consciousness up until the level of conscience that intents to dissolve or become a part of universality, its path is marked by regresses and relative advances, not by linearity. It must be assumed, in the first place, that conscience is a process, and not a good or an acquired form. Individual subjectivity goes through multiple and non-linear paths, performing overcomings and returns, however, when together, several of these subjective and reflected particularities can synthesize a unity, under favorable conditions, shaping the development of class consciousness. Within such dynamic, economical determinations and social consciences condition each other, constituting a dialectic totality.

If conscience is a mental conception of contextual social relations, therefore, an incorporation of objective reality, it is not its representation in the most integral form. At first, it is a fragmented version, for the direct perception of what is concrete to us only captures partialities, and not the concrete totality, which means, it misses the movement of historical-social totalization. The objective reality is, from the start, contextual, which motivates the transformative character of conscience and a fragmented conscience in relation to totality. The nuance of historical development is not apprehended in a first form of conscience, which results, therefore, in the naturalization (and, as a consequence, the supposed immutability) of the perceived objective reality. Thus, by taking the partialities for the whole, the individual, with such metonymic behavior, expresses an alienated consciousness, given that his or her concrete social relation is also alienated. Alienation, therefore, does not represent the stage of non-conscience, but rather its initial state. According to Iasi (2006), it is in this stage that ideology finds fertile soil to exercise its domination, molding consciousness.

Notwithstanding, the development of the "lived reality" or of the concrete mode of social relations follows a continuous movement that can enter a moment of contradiction in relation to the prevailing ideological scaffold. Therefore, by generating a period of crisis and contrast, there might be a spark of questioning in the subject who is more conscious of the environment he or she lives, and in some cases, the beginning of the conscious process of overcoming alienation. It is, then, in the moment of authenticity towards self interests and group identity that the shift in some dispositions of the concrete manner of living becomes possible. Here is the classical corresponding moment: the trade union struggle. In that sense, the strike, the collective suspension of work 
and, as a consequence, of the social relations of production, is the unique conflictual moment of this initial pressure of the subordinate class over the bourgeoisie and its domination apparatus.

However, this moment of contradiction constitutes a non-conformism that not necessarily destroys definitively the established social relations and its set of prevailing values. Let us take then, in this sense, the distinction presented by Mészáros (2008) between contingent class consciousness and its corresponding interests, and the class consciousness necessary to overcome the self-alienation of labor, essential movement for the human emancipation. Even if this initial contradiction puts the antagonistic relation between capital and labor in evidence, the worker is still dependent on the action of the other - the business owners. Thus, in capitalist society, fulfilling the demands for better work conditions might in fact turn out as a beneficial and long lasting action for capital itself. Therefore, according to Iasi (2006), the struggles which are focused on contingent demands are, in essence, a movement still marked by limitations, because when it affirms the inequalities of capital, it does not destroy it, only appeases it. If stagnated in this incipient condition of critical thought, the conscience will present the following deviant tendencies: institutionalization by careerism, by bureaucratization or by corporatism (which evidences that the process of conscience is not linear, it can regress and make new prisons and new dependances emerge).

The conscience that has been broadened in its apprehension of the totality of the social relations, as described by Iasi (2006), would express in the very negation of the class condition in capitalism so as to, when integrated to society as a whole, negate capital and thus become closer to the revolutionary goal. The subject, still only able to see the group and having as a parameter the contingent interests of a specific professional category, as is the case of most trade union demands, draws further away, still, from the subject that is self-conscious of his or her creative potential, the one that will be part of a collective historical subject and transform society, transcending the precarious group relations and the individualist needs.

The necessary shift for the working class is the one that aims at the rupture of the subordination of labor to capital, in the overcoming of such relation. The institutionalization of any reforms that do not aim at subverting the structure, but rather appeasing domination, only prolongs wage labor. This movement, however, even if it is immediatist and contingent, if completely rejected, would be an over-simplification, since it bears in itself the potential for improving the critical thought that constitutes the future practical action. After all, the movement of consciousness is not a movement that is loose from the materiality of life, but rather is a part of it and is contained by it.

However, it must be said that this last condition, contingent consciousness, only captures a part of the contradictions which the proletarian occupies in the social structure. The necessary conscience is, on the other hand, a global vision of the structural class antagonism, a perspective that transcends the conscience of isolated groups of workers towards a global conscience of the working class. Since the process of development of class consciousness has a dialectic character, the contingent movements and the institutionalization within the social-historical limitations can help cooling down the contradictions and, at the same time, develop the possibility of broadening the conscience.

Therefore, the creation of groups that tension the contradictions between the mode of production and its relations, either through demands that materialize the contingent interests or the necessary interests, are designated here as instruments of the class. Instruments because in them and through them the spaces for the constitution of the movement of consciousness 
are established, even if the very institution of these instruments, in a moment of regression in advanced progressivity, might lead the working class to the new concessions of the capital: the affirmation of capital mediated by its partial negation.

\section{Trade Union: Instruments of struggle and of constitution of Class Consciousness}

The limitations of unionism are exposed by Marx. The unionist clash that is petrified in the conflicts of purely economic nature can only draw, from its struggle, a makeshift advance, an appeasement for the ills of the capital's social-metabolism. This only pressures the acceleration of a wage fluctuation already foreseen and controlled by the Capital and, sometimes, abruptly dismantled by the advance of inflation. The worker fights for a relative increase of his share of production without opposing the social situation of exploitation he or she finds him or herself in. Still, in some cases, when there is wage increase, however, with a significant increase of the productivity of that same work force, it can be inferred that there is a relative impoverishment of the worker, even if in absolute terms he or she ends up earning a higher wage. There is no doubt that by staying in the "wage slavery" the worker remains alienated from his or her production.

Ratifying the fragility of the union's achievements aforementioned, there is for Boito Junior (2003) a relation of dependance of the Brazilian trade unions in relation to the State in the same proportion that they become independent from the workers they represent. The history of Brazilian unionism, in its relation towards capital, was one of corporatism, with rare moments of exception. The means used for the creation of this corporatism can be briefly cited as being: the Consolidation of Labor Laws [Consolidação das Leis Trabalhistas], the ideology of the LabourCapital Harmony for the development of the nation and, as a last resort, the violence - executed legitimately by the State, especially during the period of the Dictatorial Regime.

We will be limited here to the analysis of the situation of the unions in Brazil during what was called the "new unionism", that began in the late-1970s, when the country witnessed a thundering rebirth of the unionist movement. With the combative initiative of the metalworkers from São Paulo's ABC region, in May 1978, the simultaneous appearance of a new left - integrated by what would become PT (Worker's Party[Partido dos Trabalhadores]) - and other political organizations, the clash against the over-exploitation of labor rose again and renewed the guidelines of labor demands. In opposition to old unionism, constituted by the traditional left-wing, the Brazilian Communist Party [Partido Comunista Brasileiro] (PCB) and the Communist Party of Brazil [Partido Comunista do Brasil] (PcdoB), the new unionism was self-declared "combative". The members of this emergent "new unionism" designated the former unionism as one that had a corporatist tendency towards the State, concentrated in the official State politics, and not focused in the interests of the working class as a primary goal.

The 1979 strikes gathered over 3 million workers, and lasted long. Fostered by the interunion assemblies, like CONCLAT (National Conference of the Working Classes [Conferência Nacional das Classes Trabalhadoras]), the unionist movement held a number of general strikes, by categories and companies. The boom of unionism in the 1970s and 1980s, which gave birth to the Unified Workers Center [Central Única dos Trabalhadores] (CUT), would give its place, in the following decade, to a period of crisis, of relative fall of unionist intensity and, therefore, of political workers' struggle. 
The new "dried up" mode of production and the advance of neoliberal economy led to a rise of the industrial unemployment rates (FARIA, 1986). With the alterations in the technological basis of production, capital lacked the constitution of a new subject for work, supplied both by the new bonds used by companies and by the curricular university reforms, and individualized the worker even more, turning him into a "collaborator". These movements helped the capital's offensive and dominant action and aggravated the structural and organizational stability of the social movements. According to Alves (2000), the neoliberal decade - in which the country decisively stepped in, with a subaltern role, dependent on the internationalization of capital was the political process of fundamental mirroring (in relation to the capital's passive advance) for the fate of the unionist movement.

It was the dawn of a new moment, opposed to the combative boom of the 1980s, and a period of crisis in the movement was installed, defined, synthetically, by the passage from a moment of confrontation to a period of cooperation and negotiation. In other words, as described by Alves (2000, p. 121): "social conciliation, which is, no more, no less than a new kind of defensism, of a neocorporatism character." The political struggle was, therefore, downgraded from explicit confrontation to a worker's neocorporatism, of a defensive and administrative ideal, which characterized CUT's movements in the 1990s.

The first decade of the $21^{\text {st }}$ Century, in turn, presented a considerable increase in the absolute number of strikes, a fact better explained by Boito Junior and Marcelino (2010) as the unionist movement's recovery from the aforementioned structural and organizational crisis of the previous decade (it remains unknown the character of this recovery).

However, the appearance of new national trade union centers in the last decades may evidence a discontentment towards what was then the left-wing opposition, represented by PT and CUT, a Center which was historically linked to the party. The new unionist actors, in their combative origin which diverged from "old unionism", were gradually absorbed by the institutionalization following PT's rise to power, being once again coopted by the corporatist condition towards the State. As explained by Santana $(1999$, p. 11) "the union went, in the last decade [1990s], from movement to institution and from opposition to situation”. However, not without resistance from the workers.

\section{Method}

We took material objective (and objectified) reality as the general conditioning of subjectivities and concrete social relations well as Marxian dialectic. Material practice determines idea, but is also determined by it; conscience and materiality form a dynamic and dialectic whole, conditioning and reconditioning themselves. It must be noted that this entire process is a historical human construct: the production and reproduction of the correlations (and contradictions) of force in the social environment is built differently through the historical course of human practices.

It should be noted that, since it is a question of the apprehension of a totalising movement, the synthesis is not yet complete, thus not yet apprehended, since the overcoming operates in the real process of social relations in constant movement. A process which, as far as the comprehension of such contradictions is concerned, we believe to be better captured by means of a qualitative research, since, in this way, it becomes possible to minutely capture the multiple determinations involved in the unfolding of the advance of class consciousness. We will analyze the process of formation of the class consciousness constituted during the strike of the banking 
workers through the unionist collective spaces. The empirical object is constituted by the banking workers' trade union, linked to CUT, and the banking workers themselves. The data collection technique that was chosen was the semi-structured interview (9 interviews were conducted, having as a finalization criterion of the collection the exhaustion of data) and the document analysis of informational material given by the Trade Union, by the Union Opposition and the strike's leaflets, apart from articles related to the constitution of the Worker's Party (Partido dos Trabalhadores). It should be emphasized that this investigation has the scope of a particular moment, trying to locate it in the general transformative process of consciousness, however, with nointention to propose any intentionality to the historical becoming, even if it suggests indications of the current potentiality of the unionist movement in what concerns the emancipation of the working class.

To carry out the above reflection, we selected the bank workers of public banks (Caixa Econômica Federal and Banco do Brasil) of Belo Horizonte and the Sindicato dos Bancários de Belo Horizonte e Região as an empirical object of analysis. Among the records collected and consulted are: virtual union bulletins, the texts of the Collective Agreements (result of the strike negotiations of the public banks), materials from CUT Congresses, the initial strike agendas, records of the effective achievements registered on the site of the Union of Bank Workers of Belo Horizonte and Region, union bulletins, printed union newspaper, Manifesto of the Workers' Party Foundation and Charter of Principles of the same Party. The interviews were carried out in 2013 and 2014 with bank clerks from Caixa Econômica Federal and Banco do Brasil. The completion of data collection (interviews) took place according to the saturation criteria, i.e., when the new interviews do not incorporate new facts for analysis. Thus, we chose for this work seven (7) interviews whose dissertations summarize in the most explicit and shared manner the process reported by the banking group. Whether they are unionised (4) or non-unionised (3) workers, since both are more or less closely involved with the union, allowing, in turn, even in an incipient way, some interpretation of union practice as representative (or not) of the class struggle or as representative, at least, of the demands of the category.

For all the collected work, for the systematic observation of the procedures, conquests and effective practices of the union in strike coordination, and moreover, for the substance of the interviews, we will have in hands elements for theoretical analysis of the contradictions present in this particular union action, evidencing the possibilities of the enlargement of the class consciousness registered in this process. It is a question of emphasizing beforehand that the analysis will reach both the more structural elements of Brazilian unionism evidenced in the previous topic and the more singular elements of the specific category under analysis, reinforcing that the structural elements and the specific "institutional mechanisms" agglutinate in the problem of class struggle and the interdiction of its enlargement, as we will see further on by the assertions of Erik Olin Wright's theory .

The Sindicato dos Bancários de Belo Horizonte e Região has 82 years of trajectory, of historical combative mark, having participated intensely in striking movements in recent years. The institution, created in 1932, is one of the most intermittent in the labor unionist activity of the capital of Minas Gerais and defends one of the categories (the bank employees), supposedly, with more bargaining possibilities with the country's employers, given the conditions of financial expenses and political costs generated from the bank strike, in a society in which economic transactions are predominantly intermediated by the activity of this institution. It is also necessary to emphasize that this investigation cuts a particular moment, trying to locate it in the general and transformative process of consciousness, however, without being able to propose, 
we reinforce, any predictability of the historical becoming, because in Marxism history does not present a teleological movement, however, we suggest that the announcements and analyses may come to represent difficulties and current potentialities of the trade union movement with regard to the emancipation of the working class.

\section{Analysis}

The corporatism between Union and Government, comprehended in its immediate manifestation, constitutes a justification for the working class to its adaptation to capital, which allows the reproduction of the individual indignation and the collective conformism. The possibility of the movement of individual indignation resonates in the collective and creates the conditions of constitution of class consciousness, or of this same indignation leading to the adaptation of the individual to the offensives of the capital - which is the hegemonic movement among banking workers - is run through by other elements that do not run out in the form of that relation. However, although corporatism is not the determinant factor of conformism, it is conditioned by it at the same time that it conditions it, for it acts towards the reproduction of such elements inside the relation between banking workers and bankers, instead of negating them. Elements the we could distinguish in four distinct practices, which are: the bureaucratization of the trade union, the strike as a performance, the consent to the interests of capital manifested directly in the insufficiency of the achievements of the category on strike, and the non-negation of the models of management - of control - of workers in the work process. Let us see more. There are, therefore, five constitutive lineaments of union praxis under analysis that have shaped the stagnation of class consciousness in its merely contingent phase and, therefore, avoided the possibility of a major inflection of critical-practical praxis towards necessary interests (MESZAROS, 2008).

Furthermore, we would like to insert two interrelated questions for the updating of this debate that will be fundamental for our analysis, namely, 1) in relation to the position of the different employees in the context of class relations and 2) the effectiveness of the "institutional mechanisms" in the process of struggle and class consciousness:

Four general analytical strategies were developed within Marxism until the end of the 1970s, focusing on the problem of "middle class" situations in the class structure. The first strategy placed almost all of these positions within the working class; the second alternative opted to group various categories of nonproletarian wage earners under the name of the new petty bourgeoisie; another option fixed the segments of wage earners situated outside the working class into a new class called the 'professional and managerial class'; the fourth strategy interpreted these nonpolar positions as representing 'contradictory locations within class relations' (SANTOS, 1998, s/p, author translation)

Erik Olin Wright, a US sociologist, endorsed the proposition of "a structural version of the latter [strategy] by analysing three interrelated dimensions of domination and subordination within production" (SANTOS, 1998, s/p), which considered a) monetary capital, that is, the inflow of investments that acts in the sphere of production taking into account which inflection or branch has prevailed in the capital valuation process b) physical capital, that is, the instruments of production and the objects of production, the part referring, therefore, to constant capital c) labor, the labor praxis inserted in the production tuning fork. In this undertaking, "The fundamental class relationship between labor and capital was thought of as polarized and antagonistic along 
these three dimensions. Non-correspondence between the three dimensions generates", in turn, "contradictory locations within class relations" (SANTOS, 1998, s/p, author translation). In this theory, agents acting in management or supervisory activities would concretize "contradictory localizations between the working class and the capitalist class". Moreover, smaller capitalists and semi-autonomous workers would gain prominence in this novel of distinctions and contradictions:

small employers between the petty bourgeoisie and the capitalist class proper; and semi-autonomous employees between the petty bourgeoisie and the working class. These are contradictory locations because they share, simultaneously, relational characteristics of two distinct classes. Using this theoretical scheme, Wright headed the first systematic investigation of the North American class structure based on data collected from an explicitly Marxist perspective (SANTOS, 1998, s/p, author translation)

It should be pointed out that class relations are in force as an objective social relationship that defines and distinguishes a specific class sociability. Therefore, the assertives should seek to achieve class complexity without any scholastic conceptualist glow, but as a more approximate form of the existing categories. Thus, "The fundamental basis of exploitation, in turn, lies in the social relations of production. However, in the plan of this same debate, showing the different objective locations of those wage-earners, the dynamics of exploitation also becomes differentiated, according to Wright:

The concept of class should cover only exploitation rooted in relations of production and not all possible social relations in which exploitation occurs. The production-based holding should be considered a separate category from the non-productive one, because of the specific type of interdependence that is created between the holder and the operator. Other mechanisms are essentially redistributive of the surplus created within certain ownership relationships. (SANTOS, 1998, s/p, author translation)

With this in mind, in the case of bank employees, we have a process of exploitation relating to the redistribution of surplus. We can understand some more seminal considerations made by the American sociologist, namely, "The structure establishes the limits of possible variation in the formation, consciousness and class struggle" and, consequently, "imposes obstacles and opportunities to the attempts of any political actors to organize people in collective formations" (SANTOS, 1998, s/p, author translation). Given this basic Marxian notion, the material platform appears as the basis from which social praxis can emerge, whether those we have already defined as hindering, or even more powerful for the necessary class consciousness. However, here it is necessary to define an essential definition of the North American author, "the results depend on a series of factors that are structurally contingent in relation to the class structure itself" (SANTOS, 1998, s/p, author translation). This (structurally contingent) means that the most universal definitions of class structure appear as a preponderant moment, however, not sufficient for the elucidation of existing obstacles and potentials for class action. In other words, there are organizational and institutional peculiarities that may appear as decisive in defining possibilities since "The process of collective formation is decisively shaped by a variety of institutional mechanisms that are 'relatively autonomous' and that determine the ways in which structures are translated into collective actors with specific ideologies and strategies" (SANTOS, 1998, s/p, author translation). This will become even more evident when we enter our case, the analysis of a category of bank workers on strike in a particular city, as certain 'institutional mechanisms' and 
organisational specific to the category contribute to the reduction of the action potential of this particular category, which reverberates the importance of Wright's contributions to this work.

In short, if in the theoretical-methodological aspect one can abstract essential complexes and legalities, that is, establish the most universal links of a social form in its specific difference, it is known, however, that this process only works as the beginning of the trail of the real concrete. Thus, from the first analyses of the distinctive features of an object, the amplified reproduction or unveiling of the concrete whole in its "multiple determinations" will derive, making the theory valid as the most approximate representation of the entity in research, erecting the real thought. That is why, when analyzing a particular case, we do not situate ourselves only in the singularity, as soon as we learn how the universal elements condition the concrete and singular entities, thus producing the concrete, that is, the particular. In this way, the particular appears as a defined form of expression of more universal problems or of tendential laws, which endorses that the research directed to the particular case of the Union in question in this text goes back to the elucidation of major problems of the movement of a social totality. In short, as we have seen above, the structural elements and the singular contingents (institutional mechanisms) are interrelated, overdetermined by each other. In the following we will detail these institutional mechanisms (singular-contingents) and these structural elements that act, at the moment of the strike, hindering the advance of the necessary class consciousness. In this sense, it is that the systematic observation of the moment of strike, its procedures and conquests, were essential sources for demonstrating the presence of the structural elements of Brazilian unionism amalgamated with the particular institutional mechanisms of the banking category, which at that moment partially prohibited the broader development of class consciousness. With the reports from the interviews, in turn, we intend to show that the critical perception of the 'institutional mechanisms' and structural problems may point to some future potential for workers to resume the union struggle in a more offensive and fertile way in terms of the necessary class consciousness. (MESZÁROS, 2008)

\section{The bureaucratization of the Trade Union space (and, in parallel, the reproduction of domination)}

It is not misguided to mention, as the interviewees have reported, that the actions of the Union are limited by its tight link to the Unified Worker's Center (CUT) and, from it, to the Worker's Party: the well-known union entryism. However, this aspect is a part of the phenomenon, but does not express it in its magnitude, determinations and unfoldings, though it contains, in itself, the limitations of the social alterations that do not negate the bourgeois State. The State's offensive, materialized in the governmental actions concerning the trade unions, is part of the movement of affirmation of the capital's social-metabolism. To resist such offensive corresponds to the movements of negation, that therefore need the constitution of a necessary conscience - even if not sufficient. Such constitution has not been pushed forward at and by CUT. In this regard, we see the statements of Marxist thinker Mauro Iasi (2006) who in his research inflected towards the statements and results of Armando Boito (2003) that the CUT was now endorsing the so-called 'union structure'. In other words, the dangerous and corporate dependence with the State. In this line, what is found is a structural impediment to the development of class consciousness through union action, since the strike strikes take away its offensive character of class struggle. Let us see how the affirmative of interviewee 1 already demonstrates the presumably defensive character of the struggle and governed by hierarchical interests: "They said that with three weeks 
of strike they would already change the discourse. Very predictable, I did not think. Who did, the union said, wants 12 and they are offering 6, it will be 8. Very predictable" (interviewee 1)

It is not the role of this text to further describe the last 30 years of the being of the Brazilian working class beyond what has been exposed in the second item, however, by homology, we can affirm that PT's adaptation to capital, as already presented by Iasi (2006), has also happened to CUT, either because they are both instruments which were born in the same historical period, or because they are involved in a same project of society, or because the relations between the class's instruments (parties, unions, students' movements, and others) do not occur in spite of the subjects that constitute them.

When we observed the infuriated speech of the banking workers that denounced the tight link held between their union and PT as the justification to the categories' numberless losses, we evaluate that in the partiality of the movement of totalization of the consciousness, this link occurs because CUT leaves its place as government opposition and installs itself side-by-side with the instituted power, with the rise of Lula to presidency; however, the process of rise to such power is absent from the constituted conscience. Another passage that represents the defensive and subordinate vein is exposed by another worker showing, as we mentioned above, that although the strike mobilized depoliticization, the hindrance of the totality/enlargement of consciousness, the critical perception of the practice germinated in the workers:

quando eu entrei, achei ótimo, o sindicato vai defender nossa causa aqui, estão do nosso lado e contra os banqueiros. O sindicato, hoje, eu enxergo como uma mera intermediação política, na verdade. Não é intermediação, é um "meio de campo", como se fosse assim, como se eu tivesse um canal direto com o banqueiro, de modo a iludir a massa, pra conseguir benefícios irrisórios de forma a deixar a classe acalmada (interviewee 3 )

Although from a labor and classist origin, the Party built itself as the executor of a socialdemocratic plan, conciliatory towards the social cleavages, anesthetic of class antagonisms, so it could then reach executive power. The union corporatism is not built, in this historical moment, by the strength of the law or the police, as in other moments, but rather by the political horizon of the subjects that constitute this instrument and, even, those workers who do not - after all, CUT "does not act like the employer" only because PT rose to power. PT rose to power because even CUT and the workers conceded to the employer's wishes. But the rise to power exposes the bourgeois nature of the State and the impossibilities of the harmony Capital-Labor. Therefore, the link between the Union and the Party that has been denounced by the workers, which results in great losses for the worker, does not follow from a mechanical link, but from the pursued project, a project that has been demonstrating the impossibility of the overcoming of capital through the means of an institution of capital.

The argument aforementioned regarding the link between the Unionist Movement and the Government as a result not only of PT's rise to federal executive power is reaffirmed when we observe the increasing distance between the workers' representatives and its represented, a movement that has also occurred in the Party. In the moment of the strike, this distancing is expressed in a sharper way, and evidences how the "bureaucratization of the union's actions", name given to the form of organization of the union's internal procedures by the interviewees, causes the reproduction of the monopoly of the capital's domination mediated by the practice of a group of workers that have the control over the decisions of the category, as it can be seen in the assemblies where the regional delegates are elected, in the assemblies held during the 
strikes and in the negotiation tables. It can be seen that the process of emergence and emphasis of the union structure (BOITO, 2003) is proving to be quite important for the phenomenon of bureaucratization to present itself as an obstacle to class consciousness. In the observation of the strike process and in the exposition of the interviewees, "the bureaucratization of union action" always appears as a form of distancing between workers and the decision to direct the struggle. Let us see the exactness of this note:

a serviço dos banqueiros que dos bancários...só quem tá aqui que sabe, que vê, você fica desiludido, você não sente que o sindicato está aqui pra defender seu lado, ele não tá aqui pra defender o trabalhador, ele quer o dinheiro, ele quer fazer uma intermediação de apaziguação só, ele não quer o benefício real (interviewee 3)

The process of construction of the workers' declaration of demands, done nationally, evidences how the banking workers are extraneous to the union and how the way the union operates reproduces this non-involvement of those who are not organic to the organization during the year. The assemblies that choose the regional delegates are, in general, emptied and, regardless, they nominate representatives for the participation in the regional and national congresses. Since there are no mechanisms that regulate the attendance at assemblies, there is no effort dedicated to avoiding their emptying. An emptying which, often, is sought by the majority groups in the Directory, for without the everyday discussion of the subjects to be voted in the assembly, there are no guarantees that the proposals of the union's leadership are approved. As the interviewees have reported, the complexity of the themes and the divergent opinions among older members of the union hinder the active participation of new-coming workers in the union's action and discussion. The length and intensity of the punctual debates, associated with the exhaustion of the day's work, are elements that drive workers away from the assemblies. Since the themes which are dealt with are not discussed during the year with the rest of the category, the workers get lost among the arguments, but they comprehend the conflict, and remove themselves from the meetings. Thus, the preservation of democracy - the right to talk and be heard during the assemblies - becomes a mechanism of control over the result of the decisions.

Let us see, as already stated, that these processes of bureaucratization and remoteness, as reported above about the addicted dynamics of union representatives, are aimed at hindering the advance of class consciousness. However, there is an identity and a co-reflected perception among the various workers that, in a concrete and practical way, make them have some critical vision of what the union proposes/propagandizes and of what it actually conquers and executes in its strike practice, mainly. This process of mirroring and deliberation causes something transformative and critical in consciousness and, therefore, contributes to the process of broadening - albeit limited - the understanding of the structured process of class relations (IASI, 2013). That is to say, in a contradictory way, the very obstacles raised by the bureaucracy, which at first delay class emancipation, open potential doors for broadening criticism, as we can see in the statements of the workers interviewed.

This movement of controlling the process of collective decision is also used in the extraordinary assemblies called by the Strike Command, as several reports claim, as exemplified in the following speech: 
Bom, vou falar especificamente quando está fazendo a negociação coletiva. Quando o Banco apresenta alguma proposta, tem a assembleia, como que é feita essa votação? O pessoal levanta a mão. Pergunta: quem é a favor e quem é contra? E eu vejo uma (...) assim, uma contagem tendenciosa por parte do sindicato, pelo menos umas duas vezes eu notei que a quantidade de pessoas que estavam na assembleia contra o retorno, contra o fim da greve se não fosse maior era igual pelo menos, mas assim uma quantidade bastante grande de pessoas e eu notei uma contagem tendenciosa porque eu vi uma indicação da federação nacional da CUT para aceitar aquela proposta e acabar com a greve, voltar aos postos de trabalho, então por umas duas vezes eu tive essa sensação dentro da assembleia. (interviewee 4)

This feeling of political maneuver in the vote counting is intensified by the presence of workers, in the assembly, who have management functions and which are sent by the employers, with the intention of approving the end of the strike. But we will return to this point when discussing the strike as a performance. Let us see, however, that here, the Wright (1998) assertions that we developed previously appear in a very explicit way, demonstrating the contradictions present among employees due to their location in the reproduction of sociability. Managers, as we have seen, are called upon to act on behalf of the bureaucratic union system itself by inducing a vote to end the strike. It could be said that by this location, according to Wright, there would be a reproduction of domination among the wage-earners themselves, which would not involve exploitation between the owners of the means of production and the owner of the workforce. In these terms, the exploitation could be defined as "The active/exploitation link depends in each case on the ability of the controller of the asset to deprive others of access to it. Further, "The material bases of exploitation are inequalities in the distribution of productive assets, or what is usually referred to as ownership relationships. However, like Wright:

In recent times, it has been inclined to explicitly treat authority as a dimension of class relations between employees. Managers and supervisors exercise delegated power from the capitalist class to the extent that they engage in domination practices within production. This strategic position, particularly of managers, in the organization of production gives rise to the demand for a portion of the social surplus in the form of relatively high earnings. However, the position of managers does not stem only from domination relations, but also from the occupation of a privileged appropriation location within the exploitation relations (SANTOS, 1998, s/p, author translation)

Another element emphasized by the interviewees concerns the statutory rules that allow for the unrestricted permanence of the ruling group, given that the institutionalized means of action are monopolized in favor of the continuity (like the minimum number of members enrolled in the ticket, the way the elections are advertised, the utilization of financial resources, the distribution of the ballots in the most strategic agencies). If on one hand the continuity is not positive to the organization of the category, on the other it is a mechanism of individual protection for the workers who are actively involved in the union's politics because, since there is no guarantees that the union's leaders, when they leave the leadership and return to the agencies, will not be punished by the employers, they try hard not to leave their current situation. This punishment can happen in a number of ways: being transferred to agencies that are distant from their houses, being given superfluous tasks and also, the inevitable punishment: not moving up in the career. It is very revealing what we say when we explain, in the wake of Wirght, that the "institutional 
mechanisms" of each production unit and each fraction of the class act together with the structural elements weaving a particular form of "organizational control assets". As mentioned by some members of the union's leadership who were interviewed, the time dedicated to organizing the category's workers is a part of the activities which are considered in the evaluation for the career progression and thus, they return to the agencies at the starting point, as clerks.

Therefore, we noticed that the union keeps reproducing the practices and the structure of the command forms that, initially, were rebuked by the Center which they are a part of. It was previously rebuked because it was a structure that was imposed by the government, and is now accepted because it is what guarantees the permanence of the group that supports the government in charge, a permanence which is necessary either for the continuity of a certain political project, or as a strategy of individual defense.

This process of negation of the first negation is understood by the banking workers who were interviewed as the manifestation of the fact that the tendency of CUT's unionism is not to establish organizational nor operative autonomy to its workers. Centralized and vertical (effects of the bureaucratic phenomenon), the union utilizes the workers more as a justification of action than as a combat and discussion front and an instance of broadening of class consciousness. However, this incongruity, at the same that it hinders and renders the class struggle bureaucratized, leads to the elevation of the dose of critical thought regarding unionism and the paths taken in its institutionalization. A vision that is replicated by the leading and coercive molds of the established union structure and is intensely reproduced in the moment where the struggle between classes is unfurled: the strike. However, it is always necessary to remember that:

For a long time we understood ideology simply as a set of ideas. Workers shape these ideas because they are imposed by the ruling class, so that they end up constituting their world view from ideas, values and ways of thinking about themselves and the world, which are coercively imposed on them by their opponents. Marx and Engels (2007), in their work The German Ideology, formulate the following argument: it is natural that members of the dominant class, who because they are dominant own the means of production, also control the means of production and dissemination of knowledge, making their ideas be presented as universal. (IASI, 2013, p. 69, author translation)

\section{The Strike or a Striker's Performance? A practice in struggle"costume"}

If the interviewees have shown criticism towards the statutory rules and the form of participation in the ordinary assemblies, this criticism is intensified in the moment of the strike. According to the workers, the assemblies called by the Strike Command seem to be the orchestration of a great theatrical play.

The initial news of the strike leaves the banking workers on fire against their unacceptable depreciation, unthinkable for a group that bears rights and power such as the working class. The demanding union discourse, which negates the work and wage conditions that subjugate the worker coincide with the practice of each of the banking workers. It is an initial tear in the individual conscience that constitutes contingent consciousness in the direction of a necessary consciousness, but that soon resigns in the elitist and bureaucratic performance that turns its end into a foreseeable turn of events. Let us see. 
Umas duas semanas de greve e eles falam que a greve tá forte, tem que continuar, a gente vai conseguir. Chega uma [proposta de] acordo, só de meio por cento, já mudam o discurso. A greve foi boa e eu penso que temos que continuar, vocês [diretores sindicais)] falaram que estava forte" (interviewee 1)

Quando o comando nacional decide que a greve tem que acabar, independente se fechou um acordo e recebeu uma proposta boa ou não. Eles começam a fazer uma propaganda contra a greve, isso várias pessoas já perceberam na categoria, ai começam a dizer: "A gente não tá tão forte assim, vamos fazer uma assembleia, isso pode ser perigoso, pode ir pra justiça, vamos analisar melhor como que está a situação, a gente já conseguiu tanto e tal. (interviewee 7)

[...] de votar se continua ou não continua com a greve, é uma coisa forçada. O sindicato manda terminar a greve porque nesse momento é melhor terminar, não é uma votação assim, vamos colocar no papel quem quer mesmo que termine e quem não quer, o comando termina, o comando sindical termina a greve e começa ela, é assim que funciona (interviewee 2)

The conflict that is emphasized includes an irreproachable contrast: the stimulating conflicting position of the first moments of the strike and its insufficient outcome. It is the explicitness of the "theatricality" of the struggle through means of the strike, a moment that was predictably and very little victoriously built. This performance character that the strike has incorporated results from a combined, even if not orchestrated, action of the workers themselves.

An artistic act that is also performed by workers that are not involved with the trade union, but become involved when it comes down to ending the strike. The managers are led to interfere contingently in what is supposed to be the last assembly, for it will end the process of strike, with no active participation in the negotiation process whatsoever, evidencing the monopolization of the strike. Recurring indications show that such assembly will be the last one, as reported by the interviewees:

[...] todas as assembleias pra continuidade são de manhã, na Praça [Sete] onde tá fazendo a greve mesmo, a última assembleia, aquela que indica que vai acabar, é num hotel à noite. Manda os gerentes da alta gerência da agência ir lá votar, é pra fazer discurso de terminar. Quem não vota pra terminar é mal visto, como se quisesse atrapalhar pros outros. 0 pessoal que é meio neutro e da oposição não tem o que fazer porque tem mais gente lá pra acabar com a greve. Me parece que essa greve tem todo ano, mas é uma... parece um teatro (interviewee 1)

Quando eu chego em uma assembleia e eu já vejo o pessoal que está engravatado, de terno eu sei que vai acabar mesmo, não adianta, porque ali mesmo que tenha uma "pouquinha" diferença a contagem é tendenciosa, eu acho que é tendenciosa. Então realmente vai acabar a greve (...) mas a gente vê quando entra na assembleia sabe que é o último dia. (interviewee 5)

The process described demonstrates, either by systematic observation or by the critical perception of the workers, that the performative and predictable dimension of the strike is a consequence of the structural element of the union bureaucracy that goes back to the general element of what has already been called the union structure (BOITO, 2003). The conflictive questions deepened in the process of productive restructuring (FARIA, 1986) were not answered by the CUT, mainly from the CONCUT of 97 in which its conciliatory position confirmed productive restructuring as an imminent and inevitable process, even with technological modernisation, 
unemployment and worker submission. Social justice" or the redistributive character were in force to the detriment of the true and continuous seizure of the working class as a proposal for radical emancipation from the world of work. The process of internationalization and implementation of global trade pacts appears inexorable:

The defence and expansion of social rights and labour legislation within regional trade blocs (NAFTA, FTAA, Mercosur, etc.) has been one of the main strategies to promote the fight against the social and democratic deficit that characterises these initiatives. Demanding the fulfillment of these rights by governments and transnational companies, which favor the tariff facilities within these blocks, should be a priority for the ICFTU and its affiliated organizations. It is up to the CUT to expand the pressure on the Brazilian government in favor of the social dimension and adoption of the Mercosur Social Charter. (CONCUT, 1997)

The strike begins and expands by CUT's decision and is ended from the same source with no deliberation whatsoever or any decisive horizontal position, even if, in the appearance of the phenomenon, the democratic process is respected: there are assemblies and there are votes. In this last point, the employers act directly, through means of their managers who, even though are workers, incorporate the interest of the capital in ending the demands. Thus transforming the strike - an instrument of the class struggle - in a great annual spectacle that contributes very little to the category's achievements, even if it is the only moment when the category achieves something. In the movement where the struggle should change something, there is a great effort for nothing to change, however, something is always to be changed, which evidences the need of not disregarding the fought-for right to strike.

\section{The concrete consent with capital: The insufficiency of the category's achievements}

The general mood established by the strike is dubious. At the same time that it fosters the feeling of union among strikers, it puts workers who are favorable and opposed to the execution of this right in conflict. Those who do not join it see the act of strike as a manifestation of the lack of commitment of the workers with the work team, while the strikers, on the other hand, accuse of treason those who do not struggle for the interests of the category. This period, then, not only unfolds the struggle between capital and labor, but it also blooms the intra-class competition among workers, which turns the relations between work colleagues tense, and demand a certain period for the establishment of a sense of "normality" after the end of the strike. A period in which attitudes of retaliation against the strikers can be taken, like an increasing rigor in the process of evaluation performance, a determinant element in the "progression of the career".

Due to the scenario described above, banking workers with over a year working the sector consider that, if the category's gains are not significant, the cost-benefit of striking might not compensate the retaliation they suffer, because the strength of the strikers lies in the collective constituted during the strike, a strength that wanes when the workers return to the agencies, specially the smaller ones. In this sense, it is pertinent to observe the demands of the banking workers in the last years, on the following table. 


\section{CLAIMS OF BANKING WORKERS}

\begin{tabular}{l|c|c|c|c}
\hline & $\mathbf{2 0 1 4}$ & $\mathbf{2 0 1 3}$ & $\mathbf{2 0 1 2}$ & $\mathbf{2 0 1 1}$ \\
\hline Salary Reset & & & & \\
\hline $\begin{array}{l}\text { (Annual Inflation - last } \\
\text { year) }\end{array}$ & $12,50 \%$ & $11,93 \%$ & $10,25 \%$ & $12,80 \%$ \\
\cline { 2 - 5 } & $(5,911)$ & $(5,839)$ & $(6,502)$ & $(5,909)$ \\
\hline Food Aid & 32,9 & 30,8 & 28,2 & - \\
\hline
\end{tabular}

Source: Global-Rates- http://pt.global-rates.com/estatisticas-economicas/inflacao/2010.aspx (access on 16/04/2015)

Considering the information on the table regarding the salary readjustment demanded in relation to the inflation of the previous year, it is not a demand of of mere adjustment, but of real raise. However, according to the workers who were interviewed, the lack of worker participation in the strike is not due to a discontentment with the demands, but with the result of the negotiations.

[...] é justo, acho que tem que fazer [greve] sim, o ajuste 'tá' ruim, o que 'tá' reivindicando aqui é valido, mas uma coisa é o que tá na pauta mas quando chega o acordo eles aceitam uma coisa muito abaixo, muito abaixo mesmo (interviewee 2)

The following table presents the data that reinforce what the workers have expressed, given that the negotiations are finished with a deal that margins the employer's proposal, lagging considerably behind the wishes expressed in the agenda of the striker's movement.

\begin{tabular}{c|c|c|c|c}
\hline \multirow{4}{*}{2012} & $\begin{array}{c}\text { Salary } \\
\text { Readjustment }\end{array}$ & Meal Tickets ${ }^{1}$ & $\begin{array}{c}\text { Basic Shopping Basket } \\
\text { benefit } 2\end{array}$ \\
\cline { 2 - 5 } & Collective Convention & 7,5 & 21,46 & 367,92 \\
\cline { 2 - 5 } & Banking Workers Demand & 10,25 & 28,2 & 622 \\
\cline { 2 - 5 } 2013 & Bankers proposal & 6 & 20,97 & 359,42 \\
\cline { 2 - 5 } & Collective Convention & 8 & 23,18 & 397,36 \\
\cline { 2 - 5 } & Banking Workers Demand & 11,98 & 30,8 & 678 \\
\hline \multirow{3}{*}{2014} & Bankers proposal & 6,10 & 22,98 & 394,04 \\
\cline { 2 - 5 } & Collective Convention & 8,5 & 26 & 732 \\
\cline { 2 - 5 } & Banking Workers Demand & 12,5 & 32,9 & 424 \\
\cline { 2 - 5 } & Bankers proposal & 7,39 & 24,88 & 426,6 \\
\hline
\end{tabular}

${ }^{1}$ Benefit measured in Reais $(\mathrm{R} \$)$ per day worked

${ }^{2}$ Benefit measured in Reais (R\$) per month

Source; https://bancariosbh.org.br/ /author

If the representatives of the union's leadership emphasize the fact that the category is the only one with real salary gains in the last years, the workers question the magnitude of these gains, considering two aspects: 1) The salary loss through the course of the 1990s, which is close to $40 \%$ and 2) the profit margin of the banking sector in the last years, considerably larger than the rate of salary increase. Let us see:

[...] deve ser baseado no lucro do banco, na produtividade do banco. Porque seus objetivos não se baseiam nisso: na inflação para que possam aumentar os objetivos dos funcionários. [...] Eles não querem ouvir falar disso, o cara quer a 
produção ali mesmo na mesa dele. [...] Agora o sindicato está feliz o suficiente para conseguir algo acima da inflação, que seria o ganho real de que eles continuam falando. (interviewee 2)

The discourse of the interviewee shows how much the workers know about the origin of profit, however, the reasoning is abandoned in the moment where it becomes necessary to understand that there is no possible balancing between the value that was produced and the value that is appropriated by workers in the form of payment, given the relation of inverse proportionality in which the value produced is divided: wage and profit. There are several determinants which make the trade unions refrain from this task, some of which have been previously discussed in this text. All of them walk towards the movement of consent of labor to capital, the movement of regression in the advanced progression of class consciousness, as the following speech of one of the interviewed workers reinforce:

[...] pra conseguir benefícios irrisórios de forma a deixar a classe acalmada, porque se o sindicato fosse forte a gente conseguiria coisa de verdade e não paliativos, então o sindicato, eu tenho essa impressão, hoje ele está mais a trabalho, a serviço dos banqueiros que dos bancários. [...] A gente sabe que hoje o nível de consciência de classe é muito baixo, não só na categoria dos bancários, em várias categorias. Então eles não fazem esse trabalho de consciência de classe, na verdade o Marxismo pra CUT ele não existe, eles trabalham, o PT trabalha hoje com conciliação de classes, não trabalham coma consciência de classe. Eles acham que tem que conciliar o rico com o pobre (interviewee 6)

In a movement that opposes this molding there is a group that presents more radical proposals, which coincide with the contingent interests of the striking banking workers who are not organized in the trade union, however, that does not meet in them the support to follow the demands that go beyond those presented by the group leading the unions.

Quando a gente vai pra reivindicação e a gente pede 30\%, a CUT diz que isso é um absurdo, a gente tá querendo rever as perdas salariais, a gente quer diminuir essa perda salarial que o salário ficou congelado nesses [década de 1990] anos e CUT diz que isso não é válido mais, porque já passou. [...] "poxa, a gente aqui é cobrado do sindicato para pagar horas de greve", porque quando a gente vai ao sindicato fazer uma denúncia que o gerente está cobrando, eles falam: “ olha, é melhor você pagar a greve pra não criar problema”. A gente já ouviu isso várias vezes em vários anos, eu mandei um fax com a lista que a gente recebeu de pessoas que estavam sendo cobradas por horas de greve e o sindicato ignorou o meu fax, nem responderam. (interviewee 6)

The opposition group, though it negates the instituted form of representing the working class, the molding between CUT and PT, and has demands that coincide with the individual wish of banking workers, stumbles upon a determinant of the molding also present for the groups in the situation: the individual interest. Even though their demands coincide with the individual desire of banking workers, since it still presents itself as a manifestation of the collective in the instance of the individual, there is no fulfillment of practical actions in which the rejection towards current unionism converts into new unionist practices. The change remains a potency.

Let us see that the weakness in supporting the most advanced achievements, of promoting the expansion of the necessary class consciousness (MESZÁROS, 2008), faces as many problems 
of the singular "institutional mechanisms" as the very structural contradiction that conforms the working class and the wage-earners in general in a lower position of confrontation. As stated by Iasi:

Consciousness can only originate and develop as an expression of relationships that constitute the foundation of human sociability, that is, it is not a force that imposes itself on the human as the Hegelian idea or its expression in the Objective Spirit or the Absolute Spirit. Thus it does not surprise us that the immediate form of the consciousness of the working class is the expression of the same consciousness of the bourgeoisie. The proletariat does not live in other relations, it lives in the constitutive relations of capital. Therefore, the first expression of a social consciousness, which workers take as their own, is the expression of the relations they share with the bourgeoisie in the very existence of capitalist society, in its immediacy. (IASI, 2013, p. 72, author translation)

In this context, we could not fail to review the problem from Wright's perspective either:

The material interests rooted in the relations of exploration and, therefore, linked to the class structure, are real, [so that] the bond between class and consciousness [...] is based on the objective properties of the class structure itself. (...) The class experience which shapes the consciousness is always socially organized, [so that one must analyze] the social construction of the ideological categories according to which people interpret their world (SANTOS apud WRIGHT, 1998, s/p, author translation)

This aspect of individual interest prevailing over the collective and weakening the movements of demands is shielded by the juridical discussion. The jurist emphasizes that the individual right to work during the strike goes against the collective right to strike, which brings into the debate and important aspect for the organization of workers, which we will not develop in this text, but which we could not leave unmentioned, given that it is on the allegation that workers have the right to work and not join the category's strike that managers and those aspiring the "office" act as representatives of the interests of the bankers in the category of banking workers. A way for the capitalists to move the struggle between classes into the inner environment of the working class. This element is supported by the determinant which hinders the movement of class consciousness, by hindering the collective living of the individual discontentment: the banking workers career plan.

\section{The schemes of work management that instill in the worker the fear of being involved with the strike: a point that's invisible to the union}

As analyzed thus far, the workers are unsatisfied with the paltry work conditions, are unsatisfied with their union representatives and their practices, are unhappy with the achievements of the category. In an oversimplification, it could be said that the workers were willing to change these conditions. However, they do not do it. The individual discontentment does not lead to a great collective struggle. The lack of a collective living experience of the discontentment causes the possibilities of alteration of the reasons of discontentment to occur through the means of the disorganized individual struggle. 
If the union's achievements in what concerns salary are not fulfilling the category's wishes, the way out is to "progress" in the career. If the union instructs the workers to give in to the managers' pressure to work extra hours to pay for the period of strike, the exit is to go after the "promotion". The great problem posed in this harsh individual struggle is that even though it looks like the most immediate solution to solve the problem of discontentment, it sets obstacles for the change in the ways of struggling when it is noticed that it will not bring the solution.

In spite of the many talks of possibilities of promotion in the public banks, it does not exist in reality. The worker's entrance in the public banks happens through public examinations for the position of clerk. A certain salary corresponds to this position. The possibility of a salary increase - except for the category's annual raises - happens not out of the climbing to a position from another, but out of the accumulation of bonuses granted to additional functions and their corresponding commissions, as well as the loss of the right to work six daily hours. Thus, the manager of a banking agency is a clerk that took over a management function. If he or she does not perform his role satisfactorily, he or she can go back to being a clerk and will have a cut in their payment, cuts that might reduce the wage to a half. All activities pertinent to the socalled subsystems of Human Resources are considered regarding the possibility of accumulating functions: payment, training, performance evaluation, etc. These activities are presented as necessary for career progression, even though the career structure does not follow the model based on positions. In the work relations of the banking sector it can be said that this way of organizing the workers' mobility is in consonance with what is the most modern tendency: the management through competences and their occupational spaces; but what happens is that this mechanism puts and puts back the fear factor among workers.

As pessoas se sentem ameaçadas por assédio ou por medo de perder sua comissão ou por ficarem mal vistas com outros gerentes e não conseguirem comissões maiores e por isso eles se vendem no processo como um todo porque no banco não existe uma forma clara de ascensão profissional, vai de acordo com o que o gerente diz de você, da informação, referência que o superintendente tem de você, então se a pessoa for contra em alguns aspectos, ela vai ficar naquele cargo que ela entrou pra sempre. Então elas não vão reivindicar, elas querem o dinheiro no bolso delas, não vão reivindicar, acaba que o banco traz essas pessoas pro lado dele porque o processo de ascensão no banco é um processo ridículo ao extremo, não existe. (interviewee 4)

Even the formal worker evaluation programs (a passage not exposed in the excerpt, but one of the interviewees mentions such a program) are a formalist decoy. The bank managers have the authority and strategies to control and bargain the employees, imposing, subtly and informally, necessary behavior conditions to win "privileges" in the agency (positions, commissions and good references).

Several reports confirm that the structure of progression in the public banks imposes a way of dealing with the working class that is distinct from the interests of the workers themselves, because in order to fulfill the category's interests, better wages, the naturalized way is progression. However, in order to fulfill it, it becomes necessary to conduct the actions based on the interests of the bankers. Career management, an instrument developed by the bankers to tighten the chains that keep the working class as the working class with the help of the working class itself, operated by the individual worker. In this sense, the "institutional mechanisms" appear strengthened in the productive unit as a form of manipulative control and not as an objective of wage progression, 
inducing in unique ways the dynamics of social control and domination of this category. Thus, the structural conflict and manipulations of the "organizational assets" contiually reduce the collective expansion of class consciousness. What occurs, therefore, is the already identified articulation between universal elements of class structuring and the management of "organizational assets" that make workers in different "locations" (WRIGHT, 1980) control each other. Thus, what we have is a wide range of factors as we could see in the topics above, which as Wright disserts, are a coupling of both "structural" and "structurally contingent" factors.

The structure establishes the limits of possible variation in formation, awareness and class struggle and imposes obstacles and opportunities for any political actors to attempt to organize people into collective formations. Within these limits, however, a variety of political and historical factors shape the present patterns that emerge. Exploration-based interests, rooted in class structure, form the material basis for a variety of potential formations. Class structure may define the terrain of material interests around which class formation experiments occur or the underlying probabilities of different types of formation, but the results depend on a number of factors that are structurally contingent on the class structure itself. (SANTOS, 1998, s/p, author translation)

In the practical and explicit interaction, the procedural development of the complex of conditioning between 'structure', 'institutional mechanisms' and 'consciousness' is perceived. To the same extent that the real action of the union contradicts the expectations of the coreflected consciousness among the workers, the advance of their class consciousness will only be realised through the transformative and reconstructive reaction of the reality of action of the union representative of their struggle, be it in the form of formal or informal oppositions, be it in the organisation of the working mass rejecting the arbitrary definitions of the leading union elite, be it in the open confrontation of ideas that is gaining strength and establishing itself as the agenda, or in the questioning of the mode of operation of union elections. We can designate such aspects as the potential for effervescence of the struggle and the overcoming of the present obstacles, and therefore of class consciousness formation, even if they are distant from being finished facts and simply immediate.

acho que só a luta que muda as coisas, não adianta a gente mudar um presidente, não adianta a gente mudar um governador se o sistema é o mesmo, o modo de produção é o mesmo, é o modo capitalista, é o modo como eles vão administrar os bancos, é o modo como eles vão administrar as fábricas, as indústrias, o petróleo, a gente está vendo ele ser privatizando aí que é uma riqueza nacional, a única que a gente tem, uma das poucas e está sendo vendido pra estrangeiro e tal. É um problema gravíssimo, é um problema que a gente tem que discutir, a gente tem que apoiar a greve dos petroleiros que é uma greve dificílima, a gente tem que apoiar, a gente tem que ir pra rua (...) Esse freio que acontece hoje dificulta enormemente, porque muita gente se apoia ainda na CUT e acha que é um movimento que é válido, a gente sabe que é válido, ele mobiliza muitas pessoas, mas o que tem acontecido é esse atraso na consciência, a gente tem tentado mudar isso por dentro do movimento, nas categorias. (interviewee 6)

Finally, supported by the previous elucidations, we can endorse another vehement correction as to the current vulgar notion that cries out for the necessary class consciousness (MESZÁROS, 
2008) as an abstract teleology, as a natural movement in the course of the working class exercise. This teleological exercise of history is an implant of Hegel's idealistic logic in Marxian theory, replacing the Idea that reconciles itself in Absolute Spirit through the overcoming of objectivity by the working class taken as a metaphysically moved set (IASI, 2013).

\section{Final Considerations}

The four obstacles listed, which are concrete barriers to the emancipatory intention, have been allowing, in the face of the empirical relevant elements emphasized, the warming up of questionings and the emergency of other doors to reflexion and the advance of class consciousness. The questionings are confident and extensive. They aim, as explained, at the bureaucratization of the union and its hermetic effects, at the corporatism towards the State, in the paltry nature of the struggle focused on contingent interests, in the manipulative techniques of "people management" and in the protocol and artificial aspect of the strikes as an instrument of struggle.

The above conditions also show that an analysis that aims to capture the concrete cannot be fixed only on the more universal and structural elements, since both the configuration and the formation and class struggle depend on institutional mechanisms, on the manipulation of "organizational assets" that are particular to the fractions and locations of the employees in question. In other words:

Class formation is the process by which individual conditions are organizationally merged in order to generate a collective capacity to act. In this field, organizational dynamics through which individual conditions to act, as determined by class location, become mobilized into collective forms of class practice must be considered. The process of collective formation is decisively shaped by a variety of institutional mechanisms that are" relatively autonomous" and that determine the ways in which structures translate into collective actors with specific ideologies and strategies (SANTOS, 1998, s/p, author translation)

Nevertheless, what can be inferred is that although the movement evidences a critical commotion, it does not reach the threshold in which the contradiction reaches the conflictual state in which any retreat becomes an impracticable option.

Sartre calls this the "impossibility of impossibility", the moment in which there is an obstacle to existence that cannot be overcome by any means but a structural transformation. This stage is only reached when the working class transforms itself or incorporates legitimately the condition of universal class, which will represent the whole society against a general limitation to the production of the social life, in this case represented by the bourgeoisie. It would be the concrete apex of class consciousness, the summit of the process of comprehension of the totality unfolded in the ontocreative and revolutionary action. It is the consistent transformation from the "being-in- itself" into the "being-for-itself", which means, the qualitative leap from the condition of a group that is unified by reformist and common self-interests to the self-conscience of the condition and the strength of the class as the subject that makes history. However, if the head thinks from where the feet stand, as Paulo Freire emphasizes, the discussion about the movement from contingent to necessary class consciousness could not be free from the inherent contradictions of the place in which the working individual finds him or herself. This is why, in the appearance of the phenomenon, the obstacle to class consciousness and to the achievements 
of the working class is given by the relation that the Union Center holds with the party that governs the Brazilian State. This is the element which is first noticeable, however, the institution of this element has, in its obstructing determinacy to the movement of class consciousness, the element that it needs to negate a priori: the individual interests. As individuals who were socialized under the capital's mode of production, we are ideally capitalist individuals, even if not belonging to the capitalist class. To negate the ideas of the system of capital in order to negate the concrete conditions that concomitantly manage us as beings of this ideal and deny us the overcoming of the self-alienation of labor is one of the great challenges of the contemporary trade union, above all, because unionists are also under the same conditions, even if in distinct and supposedly combative spaces.

In this point we find it essential to the advance of the movement of class consciousness to negate the mechanism of inner competition in the working class. In the case of the banking workers, the "structure of positions and salaries" and the career plan turns the individual indignation into a collective accommodation. We consider, then, that the mechanisms of people management created to control the labor force during the routine work process is a determinant element of the class's molding to the capital, for they hinder the movement from individual action to collective action even for those who dare to question, for if they return to their work places they will pay individually for having rebelled collectively.

The mechanisms that could guarantee a democratic coordination of the instrument of organization of the working class, in their turn, have manifested the potentiality to be antidemocratic in the name of the execution of a political project that supposedly would allow for the overcoming of the class's self-alienation, but that in practice keeps it alienated from its own instrument of struggle. In the name of the overcoming of the alienation, the alienation is reproduced. By understanding itself as an end, it has lost itself as a mean, and in this institutional (re)constitution it reproduces, even if on the offensive, the determinants which conform the working class, remaining, therefore, still in the limits of the capital's sociability, when it does not collaborate with the reposition of its determinant elements.

Thus, every obstacle to the union praxis that was exposed and analyzed is an element of a conjuncture of molding. They build hindering conditions to the practical emancipatory action, however, they constitute a fruitful substrate for the development of class consciousness and, therefore, for questionings of how to fulfill the "progressive negation of the negation". Simply put, if the union is the first possibility of negation, when it negates the structure of capitalist domination, it still needs to negate the domination exercised by the union itself when molded to the limits of the capital's social-metabolism, expressed in the obstacles mentioned, thus allowing the progressive negation of the negation and the practical advance of consciousness.

\section{References}

ALVES, G. Do "Novo Sindicalismo" á "Concertação Social”. Ascensão ( e Crise) do Sindicalismo Brasileiro. Revista de Sociologia e Política, n. 15, p. 111-124, 2000. Disponível em: https://www.scielo. br/scielo.php?pid=S0104-44782000000200008\&script=sci_abstract\&tlng=pt Acesso em: 10 ago. 2020.

ALVES, G. O novo (e precário) mundo do trabalho: reestruturação produtiva e crise do sindicalismo. São Paulo: Boitempo, 2005.

ANTUNES, R. O Que é Sindicalismo. São Paulo: Col. Primeiros Passos, 1985 
ANTUNES, R. Os sentidos do trabalho: ensaio sobre a afirmação e negação do trabalho. São Paulo: Boitempo, 1999.

BOITO JUNIOR, A. Vargas e a herança populista. Revista Politéia, história e sociedade, v. 3, n. 1, p. 29-37, 2003. Disponível em: http://periodicos2.uesb.br/index.php/politeia/issue/view/297 Acesso em: 07 ago. 2020

BOITO JUNIOR, A. O Governo Lula e a reforma do neoliberalismo. Revista da adusp, v.34, p. 6-11, 2005. Disponível em: https://www.adusp.org.br/files/revistas/34/r34a01.pdf Acesso em: 07 ago. 2020

BOITO JUNIOR, A.; MARCELINO, P. O sindicalismo deixou a crise para trás? Um novo ciclo de greves na década de 2000. Caderno CRH, v. 23, n. 59, p. 323-338, 2010. Disponível em: https://www.scielo.br/ scielo.php?pid=S0103-49792010000200008\&script=sci_abstract\&tlng=pt Acesso em: 10 ago. 2020.

Carta de Princípios do Partido dos Trabalhadores. Disponível em: http://cspconlutas.org.br/ Acesso em: 02 jul. 2020

Congresso Nacional da CUT, 1997, CONCUT 6. Disponível em: https://admin.cut.org.br/system/ uploads/document/22b90162e8b90717a31a2988d7c23840/file/6-congresso-nacional-da-cut-6-concut13-a-17-08-1997.pdf Acesso em: 05 ago. 2020

FARIA, J. H. de. Tecnologia, processo e organização do trabalho. RAUSP, v. 21, p. 56-61, 1986. Disponível em: http://200.232.30.99/busca/artigo.asp?num_artigo=684 Acesso em: 10 ago. 2020

IASI, M. L. As Metamorfoses da Consciência de Classe: o PT enre a negação e o consentimento. São Paulo: Expressão Popular, 2006.

IASI, M. L. Educação e consciência de classe: desafios estratégicos. Pesperctiva, v. 31, p. 67-83, 2013. Disponível em: https://periodicos.ufsc.br/index.php/perspectiva/issue/view/2042 Acesso em: 07 ago. 2020

MARX, K.; ENGELS, F. A Ideologia Alemã. São Paulo: Boitempo, 2007.

MARX, K. Sindicalismo. São Paulo: Ched Editorial, 1980

MARX, K. Salário, preço e lucro. Disponível em: https://www.marxists.org/portugues/marx/1865/ salario/index.htm Acesso em: 07 ago. 2020

MARX, K. Manuscritos econômico-filosóficos. São Paulo: Boitempo, 2004.

MÉSZÁROS, I. Consciência de classe necessária e consciência de classe contingente. In: Filosogia, ideologia e ciência social. São Paulo: Boitempo editorial, 2008.

NORONHA, E. Ciclo de Greves, transição política e estabilização: Brasil, 1978-2007. Lua Nova, n.9, p. 119168, 2009. Disponível em: https://www.scielo.br/scielo.php?pid=S0102-64452009000100005\&script=sci_ abstract\&tlng=pt Acesso em: 07 ago. 2020

SANTANA, M. A. Entre a ruptura e a continuidade: visões da história do movimento sindical brasileiro. Revista Brasileira de Ciências Sociais, v. 14, n. 41, s/p, 1999. Disponível em: https://www.scielo.br/ scielo.php?script=sci_arttext\&pid=S0102-69091999000300007 Acesso em: 05 ago. 2020

SANTOS, J. A. F. A teoria e a tipologia de classe neomarxista de Erik Olin Wright. Dados [online], v. 41, n.2, p. 377-410 (versão impressa), SciELO (s/p) 1998. Disponível em: https://www.scielo.br/scielo. php?script=sci_arttext\&pid=S0011-52581998000200004\&lng=pt\&tlng=pt Acesso em: 07 ago. 2020 
Sindicato dos Bancários de Belo Horizonte e Região. Disponível em: https://bancariosbh.org.br/ Acesso em: 05 ago. 2020

WRIGT, E. O. Class and Occupation. Theory and Society. v. 9, p. 177-214, 1980. Disponível em: https:// www.aacademica.org/erik.olin.wright/53.pdf Acesso em: 05 ago. 2020. 